\title{
Who Benefits from Mobility as a Service? A GIS-Based Investigation of the Population Served by Four Ride-Pooling Schemes in Hamburg, Germany
}

\author{
Christoph Aberle ${ }^{1}$ (D)
}

Received: 6 December 2019 / Accepted: 6 March 2020 / Published online: 30 March 2020

(c) The Author(s) 2020

\begin{abstract}
The emergence of Mobility as a Service (MaaS) holds the potential to satisfy passengers' needs more flexibly than conventional public transport, while being more affordable than traditional taxi services. This paper examines the potential benefits of ride-pooling schemes for low-income urbanites. Using a GIS-based method, I examine four schemes in Hamburg regarding their coverage of public welfare recipients. Three out of four schemes potentially serve a population with a lower share of public welfare recipients compared to the Hamburg average. Furthermore, the populations in their service areas have a lower share of elderly people. One scheme stands out regarding both welfare recipient share and elderly resident share. Due to municipal requirement, its fare is much lower than the other schemes' fares. From a low-income population's perspective, only this scheme holds the potential to enable the urban poor to partake in MaaS.
\end{abstract}

Keywords Mobility as a service $\cdot$ Urban poverty $\cdot$ Transport disadvantage $\cdot$ Ride-pooling $\cdot$ Digitalisation $\cdot$ Europe $\cdot$ Hamburg

\section{Zusammenfassung}

Urbanes Ridepooling ist Teil des Versuchs, Mobility as a Service in Hamburg zu etablieren. Es bietet die Möglichkeit, klassischen öffentlichen Nahverkehr flexibel zu ergänzen. Christoph Aberles Beitrag stellt die potenzielle Nutzbarkeit des Ridepoolings für Menschen in Einkommensarmut in den Mittelpunkt. Anhand einer GIS-basierten Methode werden vier Angebote (ioki, CleverShuttle, MOIA, mytaxi match bzw. FREE NOW) hinsichtlich sozio-demografischer Merkmale der Population untersucht, die potenziell bedient wird. Bis auf einen Ausnahmefall - ioki am westlichen Stadtrand - bedienen die Anbieter zentrale Gebiete, in denen weniger Menschen arm sind, weniger Menschen alt sind und die dichter besiedelt sind als der Hamburger Durchschnitt. Diese Gebiete bieten mutmaßlich bessere Voraussetzungen für einen wirtschaftlichen Betrieb als iokis Bedienungsgebiet. Im Gegensatz dazu operiert ioki in einem Gebiet, das aus Betriebssicht nicht optimal ist - schafft damit allerdings einen konkreten Nutzen auch für Menschen in Armut.

\section{Introduction}

\subsection{Mobility as a Service, Its Social Relevance and Ride-Pooling in Hamburg}

The spatial data used for this paper can be accessed in the TUHH Open Research Repository: https://doi.org/10.15480/336.2396.2.

Christoph Aberle

christoph.aberle@tuhh.de

1 Institute for Transport Planning and Logistics, Hamburg University of Technology, Am Schwarzenberg-Campus 3, 21073 Hamburg, Germany
The ubiquitous availability of mobile devices in many urban areas holds opportunities for the provision of public mobility. The so-called Mobility as a Service (MaaS) schemes flexibly complement mass transport while being less costly than traditional taxi services. Building on information and communication technologies (ICT), MaaS comprises various modes, such as conventional bus/rail transport and bikesharing schemes as well as flexible transportation offers like 


\section{Low-income Hamburg residents} drive much less often ...
... and use public transport

more frequently than average.

\% responses of Hamburg-based participants of the National Mobility Survey (MiD), as of 2017 | n=14,666

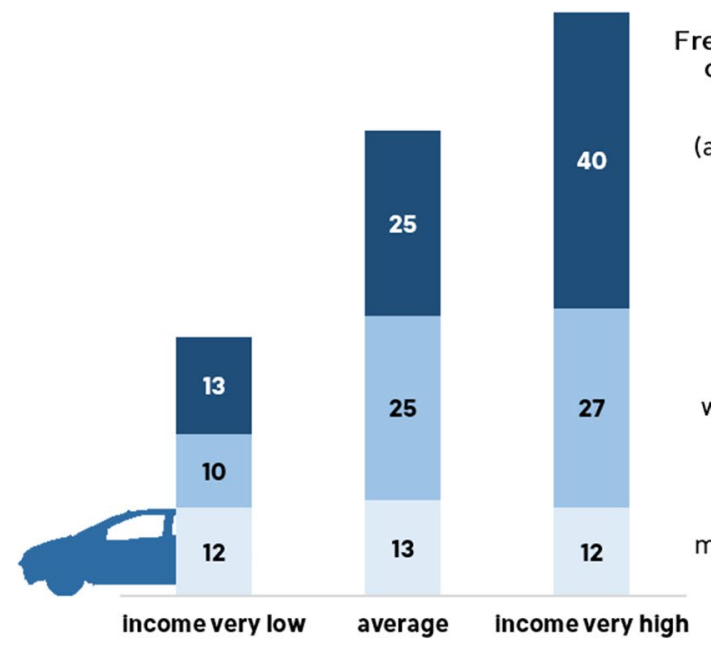

Fig. 1 Selected results of the 2017 National Mobility Survey (Mobilität in Deutschland), only responses from Hamburg. Income classes: very low $<900$ EUR per month per persons after deductions/aver-

ride-pooling, all of which are digitally presented by a single interface and are freely combinable to suit situational mobility needs (Jittrapirom et al. 2017; Viergutz and Brinkmann 2018). In this paper, my focus is on ride-pooling, defined as a commercial passenger transportation scheme that is governed by municipal administration and run by private or (partly) public operators (Deutsch 2018; Mehlert 2019).

In preparation for the World Congress on Intelligent Transport Systems (ITS) in October 2021, the City of Hamburg, Germany has declared MaaS to be one of five pillars of transport modernisation pursued within a smart city framework. Generally speaking, smart cities use ICT to innovate urban areas in several realms including mobility, environment and governance (Albino et al. 2015). Specifically, the City of Hamburg aims to improve transport efficiency, environmental performance, and liveability through ICT-based transport innovations (Bürgerschaft der FHH 2018). While the smart city framework typically focuses more on technical infrastructure than on social intervention, the City of Hamburg has also identified the aim to deliver equal mobility options for economically deprived groups (BWVI 2018).

In this context, the city has granted permissions to three ride-pooling schemes to operate: MOIA, CleverShuttle and ioki (BWVI 2019). A fourth scheme, mytaxi match (now called FREE NOW ${ }^{1}$ ), is not administratively speaking a

\footnotetext{
${ }^{1}$ In July 2019, mytaxi match was relaunched as FREE NOW. As I had obtained the research data referred to in this paper prior to the relaunch, I use the service's former name here. Also, CleverShuttle ceased operations in October 2019 due to financial reasons.
}

ride-pooling scheme, but I include it in this investigation as, from a passengers' point of view, it provides an almost identical service. ${ }^{2}$ While the ride-pooling schemes currently have an experimental character, the City of Hamburg has plans to eventually integrate them into the public transport system (Aigner 2019).

A ride-pooling journey is usually arranged and billed using a smartphone app. In contrast to a conventional taxi service, several passengers may be picked up and dropped off, and unlike conventional taxi schemes, the operator may limit the service to certain operating hours. A ride-pooling journey does not necessarily follow the shortest route but is calculated by an algorithm as a trade-off between all passengers' origins and destinations. A journey can be booked within a respective service area: the service areas referred to in this paper are shown in Fig. 2 below.

The ride-pooling operators promise to offer increased mobility for urban dwellers while curbing negative externalities of (private motorised) transport such as road congestion and air pollution. Whether these promises hold true remains open. Furthermore, alongside evidence of worse environmental performance compared to conventional public transport (Burgdorf et al. 2019; Schaller 2018) and

\footnotetext{
2 mytaxi match: it runs a taxi-booking service according to special regulation by the Passenger Transport Act/\$51PBefG and the Hamburg Taxi Directive/§2(10) Taxenordnung (mytaxi (2019)), while the other services are operated according to $\S 42 / 2(6)$ and $\S 2(7)$ PBefG, respectively. From a passengers' point of view, however, this formal difference is negligible.
} 
concerns regarding data control in smart cities (Calzada and Cobo 2015), there are issues around who benefits from digitalised services-and who does not (van Deursen and Helsper 2015). Particularly in the context of public transport-something that economically deprived persons depend on in a particular way (Lucas 2012) and that low-income citizens of Hamburg use extraordinarily often (Fig. 1) questions about the accessibility and affordability of these new services arise.

\subsection{Aim of this Paper}

This paper investigates the potential utility of ride-pooling for the urban poor population in Hamburg. Using a GISbased method, I examine four schemes regarding socio-economic indicators of the population that is potentially being served. The assumption is that the spatialised distribution of urban inequality, which has been well investigated both in a North American and a European context (Florida 2015; e.g., Marcinczak et al. 2016; Nightingale 2012), is being reflected in accessibility to MaaS schemes. Applying a spatial approach to this question contributes to understanding about the interrelations of new mobility and its utility for certain groups. On a practical note, the topic is particularly relevant as virtually all ride-pooling schemes in Germany are being run on an experimental basis for a limited time (according to §2(7) Passenger Transport Act/PBefG). It is, therefore, a key moment for political decision makers to evaluate the offers and develop suitable approaches for longterm governance (Schwedes and Rammert 2020). Further, low-income persons have so far been largely ignored as a relevant group by transport planning.

Consequentially, this paper contributes to the debate around whether, and how, new mobility can contribute to an inclusive urbanity. By focusing on public welfare recipients-a group of the German society that is vulnerable to rising living costs and more threatened by social exclusion than any other (Häußermann et al. 2004) - I argue that three of four Hamburg-based MaaS schemes do not contribute to inclusion. Ride-pooling schemes can, however, deliver utility also for low-income groups, as the fourth example shows.

\section{Method: GIS-Based Investigation Of Ride-Pooling Service Areas}

To quantify the residents who are potentially being served by the ride-pooling schemes, I applied a spatial join to the operators' service areas, to selected 2018 socio-demographics and resident data from the 2011 census. The spatial join is a well-established method to relate spatial data that originate from different sources (e.g., Wang 2006).
The service areas were derived from the operators' webpages or (where necessary) digitised manually. To obtain the share of welfare recipients (welfare according to Sozialgesetzbuch II/“Hartz IV" legislation), I used data delivered by the Municipal Statistics Body (Statistik Nord) as well as dwelling data provided by infas360. Notably, the welfare share was synthesised by dividing the absolute number of welfare recipients by the number of residents, which meant the data needed to be cleaned of artefacts (Table 1).

All data are available in a $100 \mathrm{~m}$ grid resolution. To include residents that live not within but close to a service area, I extended each service area by a buffer of $300 \mathrm{~m}$, according to a German operational standard for urban public transport catchment areas (Allgemeiner Ausschuss für Planung 2019, p. 15).

\section{Results}

\subsection{Ride-Pooling Schemes Concentrate in Areas with Low Welfare Share}

Potentially, 1.1 M Hamburg residents (62.1\%) have access to at least one ride-pooling scheme, i.e., live within at least one service area or up to $300 \mathrm{~m}$ outside the area. Relevant indicators of the four offers are summarised in Table 1.

It is noticeable that the service areas concentrate in Hamburg's core agglomeration north of the Elbe river (Figs. 2, 3 ). This might be due to the expectation of gaining a higher density of customers who are IT-savvy and willing (and able) to pay than in peripheral locations. In addition, the Elbe river forms a barrier to the southern districts, which limits the network and pooling potential throughout Hamburg. The river is only bridged by two major road connections that connect the Northern and Southern parts of Hamburg. These links (a tunnel and a bridge) are subject to congestion on a daily basis. For ride-pooling operators, they pose the risk of vehicles getting stuck in traffic jams-a situation that would jeopardise overall service level even if only few vehicles were affected.

The exception concerning service area is the ioki scheme whose service area is located on the western outskirts of the city, is considerably smaller than that of the other schemes (Fig. 2b, Table 1) and includes the large 1960s housing estate Osdorfer Born, which has been a cluster of urban deprivation for decades (Fig. 5). ioki's connection of peripheral areas to new mobility services was a precondition for the municipal administration to authorise the scheme (Aigner 2019). Furthermore, ioki journeys were initially fully included in the Hamburg public transport tariff. Since April 2019, however, a surplus fare of 1 EUR has been levied for each trip to prevent "joyrides", primarily undertaken by young people (ibid., translated by the author; VHH 2019b). 
Table 1 Operational and socio-demographic indicators of the four investigated ride-pooling schemes

\begin{tabular}{|c|c|c|c|c|c|c|c|c|}
\hline \multirow{3}{*}{$\begin{array}{l}\text { Ride-pooling } \\
\text { scheme }+300 \mathrm{~m} \\
\text { buffer }\end{array}$} & \multicolumn{4}{|c|}{ Operational indicators of the ride-pooling schemes } & \multicolumn{4}{|c|}{$\begin{array}{l}\text { Socio-demographic indicators of the population potentially } \\
\text { served by the ride-pooling schemes }\end{array}$} \\
\hline & $\begin{array}{l}\text { Size of ser- } \\
\text { vice area }\end{array}$ & $\begin{array}{l}\text { Share of set- } \\
\text { tlement area }\end{array}$ & $\begin{array}{l}\text { Dwelling den- } \\
\text { sity, measured } \\
\text { by settlement } \\
\text { area (for } \\
\text { service areas } \\
\text { incl. } 300 \mathrm{~m} \\
\text { buffer) }\end{array}$ & Fare for $5 \mathrm{~km}$ & $\begin{array}{l}\text { Potentially } \\
\text { served resi- } \\
\text { dents }\end{array}$ & $\begin{array}{l}\text { Share of } \\
\text { potentially } \\
\text { served resi- } \\
\text { dents }\end{array}$ & $\begin{array}{l}\text { Share of } \\
\text { persons } \\
\text { on public } \\
\text { welfare }\end{array}$ & $\begin{array}{l}\text { Share of per- } \\
\text { sons older than } \\
64 \text { years }\end{array}$ \\
\hline & $\mathrm{km}^{2}$ & $\%$ & Residents $/ \mathrm{km}^{2}$ & EUR/ride ${ }^{\mathrm{a}}$ & Persons & $\%$ & $\%$ & $\%$ \\
\hline ioki & 20 & 5 & 6,532 & 1 & 73,680 & 4.0 & 19.9 & 20.9 \\
\hline CleverShuttle & 134 & 26 & 14,267 & $5-6$ & 809,382 & 44.4 & 12.0 & 18.5 \\
\hline mytaxi match & 141 & 22 & 15,857 & $9-12$ & 775,872 & 42.5 & 12.3 & 18.2 \\
\hline MOIA & 211 & 46 & 10,550 & $5-8$ & $1,080,271$ & 59.2 & 13.5 & 18.9 \\
\hline Combined & 240 & 49 & 10,489 & $\mathrm{n} / \mathrm{n}$ & $1,133,458$ & 62.1 & 14.0 & 18.9 \\
\hline $\begin{array}{l}\text { Hamburg aver- } \\
\text { age }\end{array}$ & $\mathrm{n} / \mathrm{n}$ & $\mathrm{n} / \mathrm{n}$ & 8,267 & $\mathrm{n} / \mathrm{n}$ & $\mathrm{n} / \mathrm{n}$ & $\mathrm{n} / \mathrm{n}$ & $14.9^{\mathrm{b}}$ & 19.1 \\
\hline Reference date & 2019 & 2018 & 2018 & 2019 & 2018 & 2018 & 2018 & 2011 \\
\hline Data source & $\begin{array}{l}\text { Own calcula- } \\
\text { tion based } \\
\text { on service } \\
\text { areas }\end{array}$ & $\begin{array}{l}\text { Hamburg } \\
\text { Ministry } \\
\text { of Urban } \\
\text { Develop- } \\
\text { ment and } \\
\text { Housing } \\
\text { (BSW) }\end{array}$ & infas360/BSW & $\begin{array}{l}\text { Own booking } \\
\text { requests }\end{array}$ & infas 360 & infas 360 & $\begin{array}{l}\text { infas360/ } \\
\text { Hamburg } \\
\text { Statistics } \\
\text { Body }\end{array}$ & Census \\
\hline
\end{tabular}

${ }^{a}$ Costs derived from $5 \mathrm{~km}$ booking requests from an address in Hamburg's Central Business District (Große Theaterstraße 1A) to a destination in a residential area (Lortzingstraße 8). The requests were deployed three times for each scheme at different times of day. All schemes besides ioki charge variable prices depending on origin/destination, time of day, and other passengers' demand. Furthermore, ioki only operates in a small area (see Fig. 2) and cannot offer rides across the city. If combined with conventional transport, the individual ticket fare has to be added to the 1 EUR cost of this, thus, only a very general comparison can be made

${ }^{\mathrm{b}}$ The welfare share is higher than the real share, as low numbers were blurred by the Statistics Body due to privacy reasons. Each census cell with $<10$ residents on welfare was assigned the value $5(8,116$ of 12,931 cells, equalling $62 \%)$. As a consequence, cells with a population of $<20$ were excluded from the analysis as they would distort the welfare share for the higher. The number of excluded cells is 894 (6.9\%). According to the Statistics Body, the average welfare recipient share for Hamburg is 9.7\%. However, for this indicator I am interested in the relationship between the different schemes and the Hamburg average. Using a slightly different methodology, I have compared the schemes using a lower spatial resolution and found similar results; see Aberle (in press)

Figure 3 shows the area served by at least one ride-pooling scheme, representing $32 \%$ of the municipal territory or $49 \%$ of Hamburg's settlement area (Table 1). Thus, generally speaking, Hamburg's ride-pooling schemes operate in areas that already have a decent level of public transport service. As Fig. 3b shows, however, there exist areas in between railway corridors that benefit from ride-pooling. One of these service gaps is filled by ioki, as Fig. 5 points out.

\subsection{The Urban Poor are Underrepresented in Ride-Pooling Service Areas}

People living on public welfare are underrepresented when it comes to the three large ride-pooling schemes: in the service areas of CleverShuttle, MOIA and mytaxi match, the public welfare recipient share is lower than the Hamburg average. It is only in ioki's service area that the share exceeds the average (Table 1, Fig. 4). The same applies to the share of persons older than 64: only ioki serves a higher share of elderly people compared to the Hamburg average.

In terms of dwelling density, ioki's indicator also deviates from the others: unlike the other ride-pooling schemes, ioki serves an area that is $21 \%$ less dense compared to the Hamburg settlement area. The larger schemes in turn cover areas that are much more densely populated (Table 1).

\section{Discussion}

\subsection{Ride-Pooling Does Not, Per Se, Deliver Substantial Utility for Low-Income Groups ...}

The results fit into the well-replicated finding that the distribution of socio-economic characteristics is spatially 

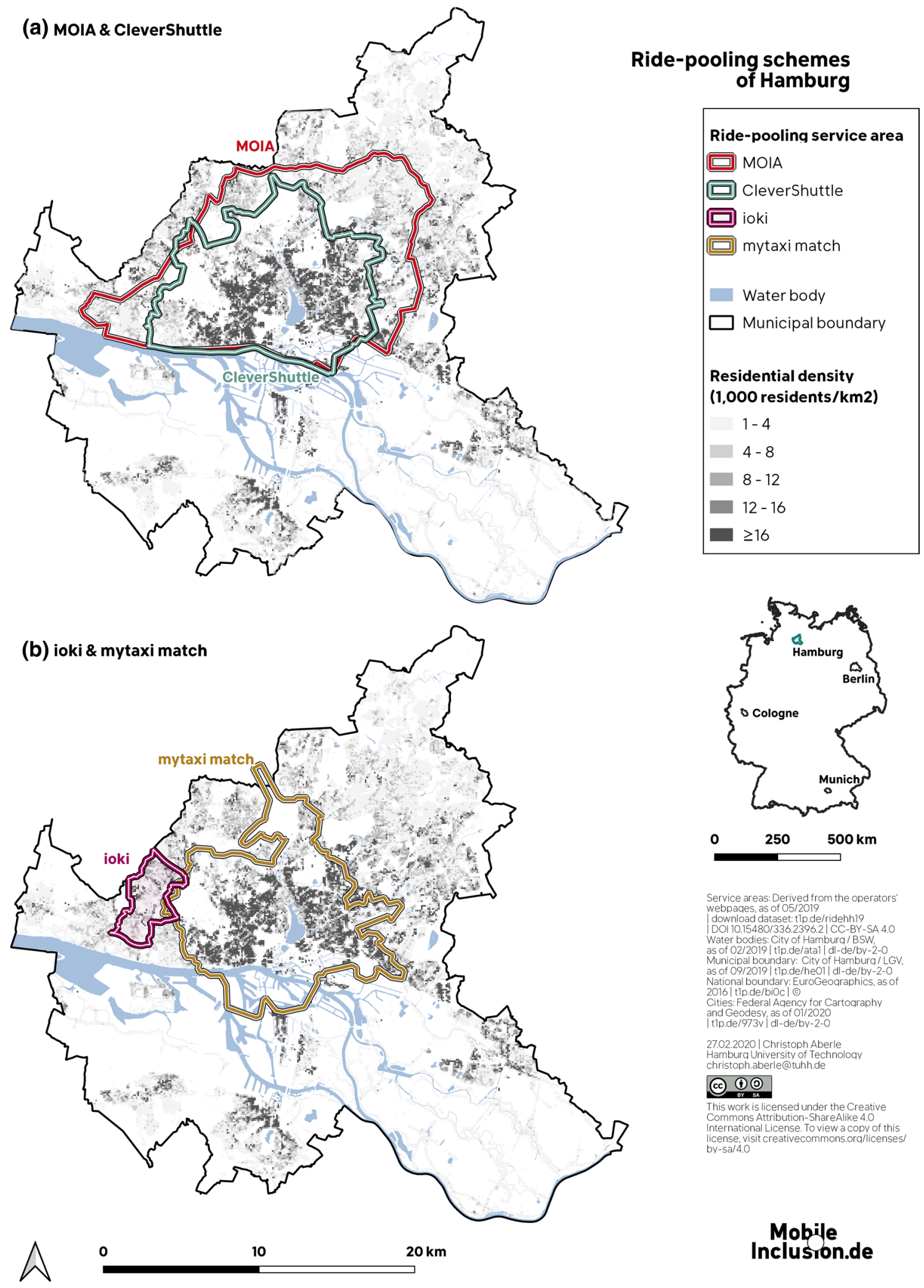

Service areas: Derived from the operators'

I download dataset: tip.de/ridehh19

| DOl 10.15480/336.2396.2 | CC-BY-SA 4.0

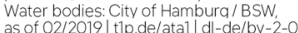

as of $02 / 2019$ | t1p.de/atal dl-de/by-2-0

as of $09 / 2019 \mid$ thp.de//he01| da-de/l/by-2-0

National boundary: EuroGeographics, as
2016 t t1p.de/bioc 1 (c)

Cities. Federal Aaency

and Geodesy as of 0112020 Cartography

| tlp.de/973v | di-de/by-2-0

27.02.2020 / Christoph Aberle Hambura nniversity of Technolocy
christoph.aberle@tuhn.de

\section{(c) (1) (2)}

This work is licensed under the Creative

International License. To view a copy of this

license. visit creativecommons.ora/licenses/

\section{Mobile Inclusion.de}

Fig. 2 a Service areas of MOIA and CleverShuttle; b service areas of ioki and mytaxi match. For the GIS-based calculations I added a 300 m buffer, which is not depicted here 
(a) all public transport modes

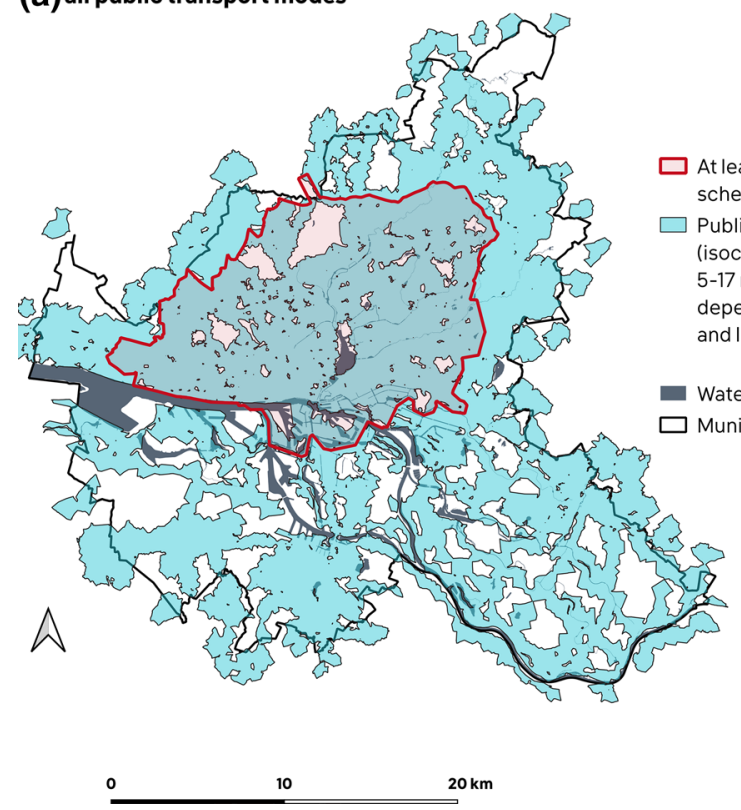

(b) railway stations only

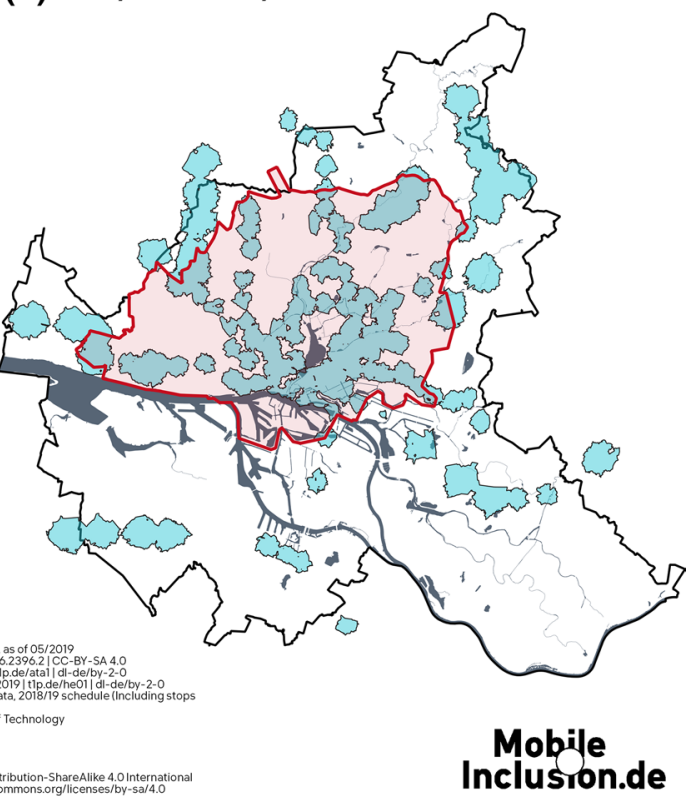

Fig. 3 Comparison of the area that is served by at least one ride-pooling scheme and the catchment area of public transport stations a for all public transport modes, $\mathbf{b}$ for railway only

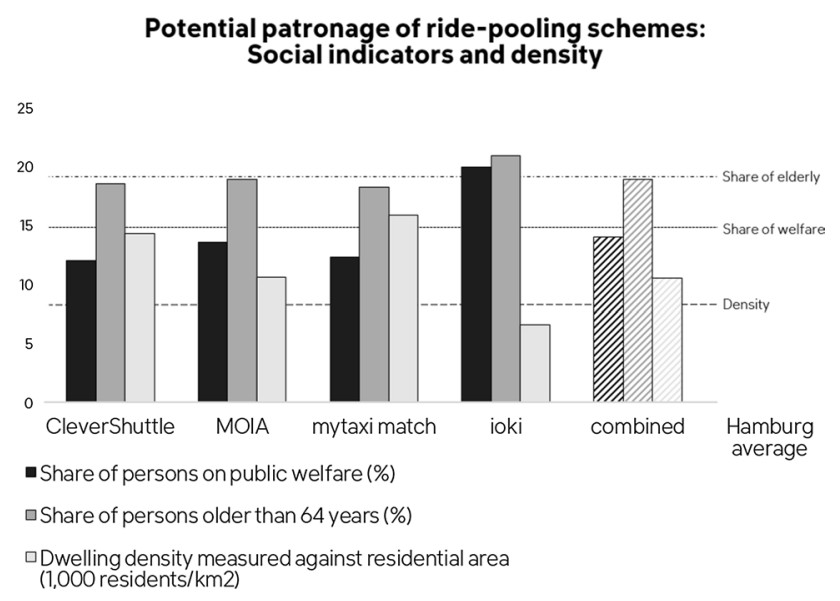

Fig. 4 Comparison of social indicators for four ride-pooling schemes in Hamburg

uneven (Florida 2015, 2017; Nightingale 2012). The concentration of urban income poverty in German agglomerations has been a persistent feature for decades, especially when it comes to large peripheral housing estates (Runge 2005). For MaaS providers, these peripheral districts apparently do not hold sufficient potential to run their schemes profitably. As a result, marginalised and 'poor' neighbourhoods are underserved by the large schemes. This is reflected in the indicators shown in Table 1: the population served by the three large schemes is less poor and less old than the Hamburg average, while the service areas are more densely populated.

\section{2 ... But When Governed Well, it Opens Opportunities for Everyone-Including the Urban Poor}

The exception is the ioki scheme, which was obliged by the public administration to operate in a remote area. The operation district has been lacking a decent railway connection for decades. Thus, ioki represents a case where a ride-pooling scheme makes a substantial difference to accessibility of (sub-)urban rail transport. As an evaluation of operations indicates, more than half of the ioki trips have indeed been used to reach railway stops and larger bus nodes (VHH 2019a).

The relatively high welfare share within ioki's service area is tightly linked to its size, spatial location, and dwelling density. As Fig. 5 below shows, the Osdorfer Born housing estate lies in the centre of ioki's service area, being home to $14.6 \%$ of the population served by the scheme while comprising only $5.6 \%$ of the service area. While covering a remote residential area, ioki does not include, e.g., the central business district (CBD). Meanwhile, the other schemes are large in size and cover the CBD and more 'affluent' 


\section{Decentral ride-pooling enhances railway accessibility for "Osdorfer Born" dwellers \\ service area of ioki \\ -.:- Large housing estate "Osdorfer Born" \\ (5 Urban railway stop ("S-Bahn") \\ Municipal boundary \\ Water body}

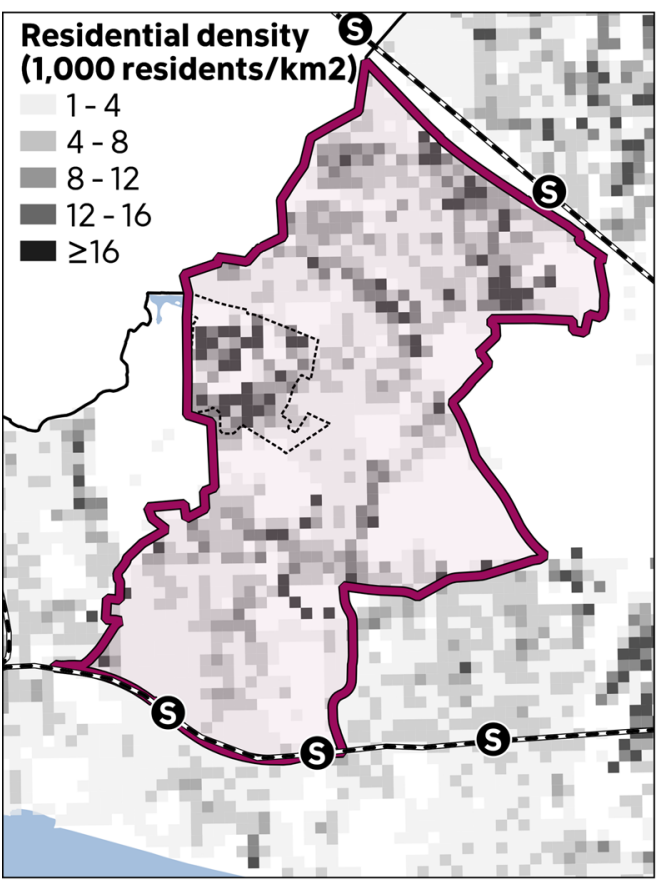



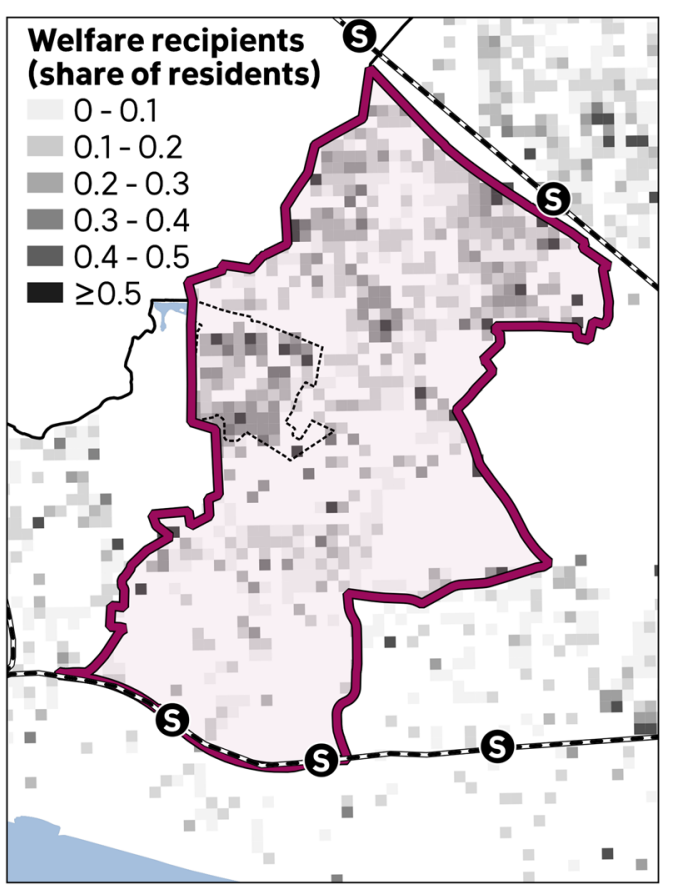

$4 \mathbf{~ k m}$
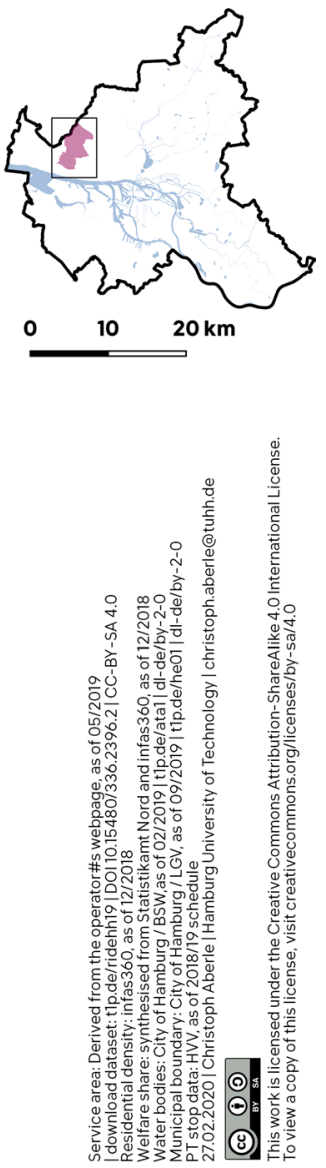

Mobile Inclusion.de

Fig. 5 Density and welfare distribution as well as railway access of residents within the ioki service area

districts as well as some 'poor' neighbourhoods (both indicated by welfare share). Overall, their socio-economic indicators might approximate the Hamburg average due to their spatial attributes rather than an agenda that lacks inclusivity. In other words, the three large ride-pooling schemes arebesides the fare-probably not less socially accessible than ioki per se. It might simply be that their extensions and spatial compositions cause their respective welfare shares to be lower. Similarly, ioki's high coverage of urban poor is likely to be a well-intended result of the scheme's spatial attributes.

For some low-income inhabitants of ioki's service area, as interview results of my colleague Stephan Daubitz reveal, the ride-pooling scheme indeed turns out to be useful:

"Four or five times [I've used ioki] when I went to the local food bank. Well, on the bus you wouldn't get [your groceries] carried [...] all the way home."

The statements concerning ride-pooling are manifold, ranging from appreciation (as quoted above) to suspicion that the scheme is only a means to tranquilise locals who have been complaining about a lack of transport options for decades. As another interviewee puts it: "[ioki was] also [started] with the intention to sedate us" (Daubitz and Aberle 2020/excerpts of the presentation, translated by the author).

Since the focus of this paper lies on the GIS-based investigation of service areas, an in-depth discussion of welfare recipients' perception of ride-pooling schemes is beyond its scope (particularly, as MaaS was only a minor topic within the interviews). However, it is notable that all five interviewees who live in ioki's service area know the scheme and instantly take up a stance on it. This contextual finding indicates that the respondents consider ride-pooling to be one option among many to meet situational mobility needs - which is, as explained in the introduction, one of the key qualities of MaaS. 


\section{Conclusion}

New forms of urban mobility hold the potential to supplement existing transport services. Ride-pooling schemes can complement conventional services while being more flexible than traditional public transport and more affordable than taxi services.

In Hamburg, ride-pooling is only available north of the Elbe river. The schemes mainly cover areas that already have a decent level of public transport service, although they also partly serve areas that are not served by railways. Three of four experiments (i.e., MOIA, CleverShuttle, and mytaxi match) are being carried out in areas where the population is more densely distributed, younger and less depending on public welfare than the average population. An exception is presented by the ioki scheme on the western outskirts, which serves a remote district due to municipal requirement. From the urban poor's point of view, ioki offers an additional benefit that might be affordable even on a low income. The underlying public governance facilitates a MaaS scheme that is not cost-effective for the municipality/city but does address the urban poor.

This paper has highlighted the interrelation of ride-pooling services and the opportunity of access for economically deprived urbanites. By presenting a stance on inclusive urbanity, the results amend the debate around MaaS, which has so far mostly been focused on technical solutions. Further research can extend the analysis by considering more factors of deprivation risk such as, e.g., low purchasing power or gender-related restraints of mobility. Additionally, the methodology can be enhanced towards spatial statistics. Furthermore, the analysis of actual MaaS use, which is being carried out progressively by the operators, will be fruitful in this realm.

Whether, and under which conditions, MaaS will become an integral part of Hamburg's public transport remains to be seen once the experiments in preparation for the 2021 ITS Congress have ended. As this paper wants to point out, success is not to be measured only by the performance of the ride-pooling algorithms - but also by the question of who can partake in new mobility.

\begin{abstract}
Acknowledgements Open Access funding provided by Projekt DEAL. This paper is a product of the MobileInclusion project funded by the German Research Foundation for which my colleagues and I are investigating the relationship of social inequality and urban mobility (www. mobileinclusion.de/en). Special thanks go to Jule Lietzau for helping to digitise the service areas.
\end{abstract}

Funding This work was supported by the German Research Foundation, Bonn/Germany [Grant number 382428751].

\section{Compliance with ethical standards}

Conflict of interest None.
Open Access This article is licensed under a Creative Commons Attribution 4.0 International License, which permits use, sharing, adaptation, distribution and reproduction in any medium or format, as long as you give appropriate credit to the original author(s) and the source, provide a link to the Creative Commons licence, and indicate if changes were made. The images or other third party material in this article are included in the article's Creative Commons licence, unless indicated otherwise in a credit line to the material. If material is not included in the article's Creative Commons licence and your intended use is not permitted by statutory regulation or exceeds the permitted use, you will need to obtain permission directly from the copyright holder. To view a copy of this licence, visit http://creativecommons.org/licenses/by/4.0/.

\section{References}

Aberle C (2020) Mobility as a service - an opportunity for the urban poor? GIS-based investigation of four ride-pooling schemes in Hamburg/Germany. Proceedings of 8th Transport Research Arena TRA 2020, April 27-30, 2020, Helsinki, Finland (in press)

Aigner L (2019) Der HVV - Vom Verkehrs- zum Mobilitätsverbund?: Vortrag bei der DVWG Hamburg e.V., 9 May 2019, Hamburg

Albino V, Berardi U, Dangelico RM (2015) Smart cities: definitions, dimensions, performance, and initiatives. J Urban Technol 22:3-21. https://doi.org/10.1080/10630732.2014.942092

Allgemeiner Ausschuss für Planung (2019) VDV-Schrift 4: Verkehrserschließung. Verkehrsangebot und Netzqualität im ÖPNV, Köln

Burgdorf C, Karl A, Müller M, Nakkash N, Schaaffkamp C (2019) Perspektiven zur effizienten Nutzung von neuartigen Mobilitätsangeboten, Berlin. https://www.vzbv.de/sites/default/files/20191001_gutac hten_vzbv_final.pdf.

Bürgerschaft der FHH (2018) Fortschrittsbericht der ITS-Strategie. Fortschrittsbericht der ITS-Strategie, Mitteilung des Senats an die Bürgerschaft

BWVI (2018) Mobilität in Hamburg - Die Ziele: Leitbild und Handlungsziele der Verkehrsentwicklungsplanung in Hamburg. https://www. hamburg.de/contentblob/11221886/3511bd3ab7a5f10b1e8b112b4 63efef4/data/mobilitaet-in-hamburg-\%E2\%80\%93-die-ziele.pdf.

BWVI (2019) DIGITALISIERUNG DES VERKEHRS: Hamburgs ITSStrategie: Lösungen für die urbane Mobilität und Logistik von morgen. https://www.hamburg.de/contentblob/11607430/b94bc27a6e c119c0d2ba1b11e8e49adc/data/its-broschuere-hamburg.pdf.

Calzada I, Cobo C (2015) Unplugging: deconstructing the smart city. J Urban Technol 22:23-43. https://doi.org/10.1080/10630 732.2014 .971535

Daubitz S, Aberle C (2020) Neue Mobilitätsangebote: Gewährleisten sie gesellschaftliche Teilhabe für Einkommensarme? In: Rethinking Spaces. Planning in a Changing World. Dortmunder Konferenz Raum- und Planungsforschung, Dortmund. 17.02.2020, p. 139

Deutsch V (2018) Weniger oder mehr Verkehr - Auswirkungen von Uber, Lyft \& Co. auf das Verkehrsaufkommen in Städten. Straßenverkehrstechnik, p p815-818

Florida R (2015) Inequality and economic segregation are on the rise in European cities, Too. CityLab. https://www.citylab.com/ life/2015/11/economic-segregation-and-inequality-in-europes-citie s/415920/. Accessed 31 Jan 2019

Florida R (2017) The new urban crisis: How our cities are increasing inequality, deepening segregation, and failing the middle class - and what we can do about it. Basic Books, New York, p 310

Häußermann H, Kronauer M, Siebel W, Vogel B (eds) (2004) An den Rändern der Städte: Armut und Ausgrenzung, 1st edn. Suhrkamp, Frankfurt am Main, p 343

Infas (2019) Ergebnisse der Studie Mobilität in Deutschland (MiD) Stadt Hamburg: Präsentation für die Metropolregion Hamburg. https ://metropolregion.hamburg.de/mobilitaet/12739928/mid2017/. 
Jittrapirom P, Caiati V, Feneri AM, Ebrahimigharehbaghi S, González MJA, Narayan J (2017) Mobility as a service: a critical review of definitions, assessments of schemes, and key challenges. UP 2, 13-25. 10.17645/up.v2i2.931

Lucas K (2012) Transport and social exclusion: Where are we now? Transp Policy 20:105-113. https://doi.org/10.1016/j.tranp ol.2012.01.013

Marcinczak S, Musterd S, van Ham M, Tammaru T (2016) Inequality and rising levels of socio-economic segregation: Lessons from a panEuropean comparative study. In: Tammaru T, Marcinczak S, van Ham M, Musterd S (eds) Socio-economic segregation in European Capital Cities. East Meets West, vol. 89. Routledge, pp. 358-382

Mehlert C (2019) Transport-on-demand: Alles Uber, oder was?: Vortrag auf der DVWG-Veranstaltung „MOIA \& CO: Konsequenzen von On-Demand-Shuttle-Angeboten für ÖV- und Taximarkt“, 10 April 2019, Hamburg

mytaxi (2019) Allgemeine Geschäftsbedingungen für mytaxi sharing service Festpreis (derzeit angeboten unter der Bezeichnung ,match Festpreis“) für Fahrgäste. https://mytaxi.com/fileadmin/Legal _Documents/Germany/190402_mytaxi_match_service_Festpreis_ Passenger_Hamburg_inkl_Sondervereinbarung.pdf.

Nightingale CH (2012) Segregation: a global history of divided cities. University of Chicago Press, Chicago, p 540

Runge D (2005) Mobilitätsarmut in Deutschland? TU Berlin, Fachgebiet Integrierte Verkehrsplanung, Berlin, $25 \mathrm{Bl}$.
Schaller B (2018) The new automobility: Lyft, Uber and the Future of American Cities, New York. https://www.schallerconsult.com/rides ervices/automobility.pdf.

Schwedes O, Rammert A (2020) Zur Governance von MaaS: Mobilität erfolgreich steuern, In: Rethinking Spaces. Planning in a Changing World. Dortmunder Konferenz Raum- und Planungsforschung, Dortmund. 17.02.2020, p. 136.

van Deursen AJAM, Helsper EJ (2015) The third-level digital divide: who benefits most from being online? In: Robinson L, Cotten SR, Schulz J, Hale T, Williams A (eds) Communication and information technologies annual. Digital distinctions and inequalities. Emerald Group Publishing Limited, Bradford, pp 29-52

VHH (2019a) Innovativer ioki Shuttle-Service erfolgreich etabliert. https ://vhhbus.de/ioki-shuttle-service. Accessed 27 Feb 2020

VHH (2019b) VHH und ioki bauen Angebot in Hamburg weiter aus. https ://vhhbus.de/ioki-aufpreis/. Accessed 31 May 2019

Viergutz K, Brinkmann F (2018) Ridepooling: Ein Erfolgsmodell? Digitalisierung im Nahverkehr. Ridepooling: a model for success? Digitalization in local public Transport. SIGNAL+ DRAHT, 13-18.

Wang F (2006) Quantitative methods and applications in GIS. CRC Press, Boca Raton 